\title{
CHROMOSOMAL INTERCHANGES AND THE PHYLOGENY OF WHEAT
}

\author{
RALPH RILEY, HELLI COUCOLI* and VICTOR CHAPMAN \\ Plant Breeding Institute, Cambridge, England
}

Received I9.vii.66

\section{INTRODUCTION}

BREAD wheat, Triticum estivum, is one of the primary sources of human food. There is consequently a natural curiosity concerning the origins of the plant upon which man has for so long depended, and which has supported the development of many of his most advanced civilisations. Some comprehension of the evolutionary origins of wheat is clearly essential for any adequate interpretation of the early histories of the human cultures that originated in the region of the eastern Mediterranean. One object of the present work was to attempt to determine the form of $T$. estivum that was first available to the agriculturalists of that region.

The general evolutionary origins of $\mathcal{T}$. estivum are well understood. It is a 42-chromosome allohexaploid-genomically AABBDD-in which the full chromosome complements of three closely related I4-chromosome diploid species are combined (Riley, I965). The advance to the allotetraploid condition resulted from hybridisation between Triticum monococcum, genomically AA, and Egilops speltoides, genomically BB. Doubling of the chromosome number of the otherwise sterile hybrid gave rise to the AABB tetraploid species, such as Triticum turgidum ssp. dicoccoides $(2 n=4 x=28)$, and there was subsequent divergence into numerous distinct forms at this level of polyploidy. Hybridisation between an allotetraploid of this type and Egilops squarrosa, genomically DD, followed by doubling of the chromosome number in the triploid hybrid, gave rise to the 42-chromosome hexaploid, AABBDD, species.

Subsequent divergence produced a range of distinct morphological forms at the hexaploid level. These have sometimes been assigned specific and sometimes subspecific rank, but the latter seems more reasonable since many of the major distinguishing characters are simply inherited. The most recent taxonomic treatment places all the hexaploids in the species $T$. estivum and gives the distinctive forms the subspecific names, vulgare (bread wheat), compactum (club wheat), spelta (large spelt or dinkel wheat), spherococcum (Indian dwarf wheat) macha and vavilovi (MacKey, r954a).

Considerable discussion has ranged around the problem of which of these forms is the most primitive and was first available to agriculture.

* Present address: Department of Botany, University of Thessaloniki, Greece. 
It is assumed that, from this prototype hexaploid, all the others arose. An important consideration in these discussions has been the geographical region in which hybridisation between tetraploid wheat and $E$. squarrosa might have occurred. This is apparently delimited by the area occupied by $E$. squarrosa, which at the present time extends from the most easterly shores of the Black Sea, round the southern shores of the Caspian Sea, through Iran and into Afghanistan and north-west Pakistan. While it is recognised that, at the time of the origin of hexaploid Triticum, the distribution of $A$. squarrosa may have been different, the present distribution constitutes the only guide. Over the whole of the area now occupied by $E$. squarrosa, tetraploid wheat can be expected to have been present.

Because it has the apparently primitive characteristics, brittle rachis and closely invested grains, ssp. spelta was for long thought to be the original hexaploid, but Schiemann (I93r) considered this unlikely because of its restriction to a limited area of south-western Europe. However, the notion was revived by McFadden and Sears (1946) because of the morphological similarity to ssp. spelta of the synthetic hexaploid derived from T. turgidum ssp. dicoccum $\times \mathbb{E}$. squarrosa hybrids. They suggested that ssp. spelta had originated in the Caucasus region, where $A$. squarrosa and $T$. turgidum both occur at the present time, and that it had been transported from there to become relict in southwestern Europe. During its wider distribution ssp. spelta was postulated to have constituted the stock from which the other hexaploid forms had arisen. Schiemann (I95I) pointed out, however, that there was no evidence of a wider distribution and argued that traces of the spread of ssp. spelta should remain if the events had been as McFadden and Sears supposed. Subsequently Kuckuck (I 959) reported that ssp. spelta is cultivated at present in the Baktiari region of Iran, about 250 miles north-east of the mouth of the Tigris-Euphrates. This confirmed a neglected report of brittle-rachis wheats in the same area by Aaronsohn (I9Io). Obviously the occurrence of ssp. spelta in this area must to some extent invalidate Schiemann's objections to it as the most primitive hexaploid. However, the simple single gene distinction between ssp. spelta and ssp. vulgare clearly does not preclude the independent origin from ssp. vulgare of the forms of ssp. spelta found in Europe and Iran.

Partly on the archeological evidence of the compact-headed, Lakedweller wheat, T. antiquorum, of Switzerland, MacKey (r 954b) suggested that the most ancient contemporary hexaploid is ssp. compactum. $\mathrm{He}$ also proposed that it was by the acquisition of the dominant gene $C$, the presence of which distinguishes ssp. compactum from all the other subspecies, that hexaploid wheat first attained a tough-rachis condition. This conclusion was reached because in MacKey's view the first hexaploid must have had a brittle rachis.

There is little evidence to support any of these opinions about the nature of the first hexaploid wheat or to indicate which of the contemporary forms is the most primitive. Indeed, apart from an 
understanding of the inheritance of differences in certain diagnostic morphological characters, the nature of the evolutionary relationships of the various subspecies are unknown. However, chromosomal interchanges are relatively common in Triticum and a number have been identified (table I). It seemed likely that, by tracing the distributions

TABLE I

Identified interchanges in Triticum

\begin{tabular}{|c|c|c|c|}
\hline Parents* & $\begin{array}{c}\text { No. } \\
\text { interchanges }\end{array}$ & $\begin{array}{l}\text { Chromosomes in } \\
\text { interchanges }\end{array}$ & Authority \\
\hline $\begin{array}{l}\text { Chinese Spring-ssp. carthlicum } \\
\text { Chinese Spring-ssp. compactum (Poso) } \\
\text { Chinese Spring-Holdfast } \\
\text { Chinese Spring-Cappelle-Desprez } \\
\text { Chinese Spring-Indian } \\
\text { Chinese Spring--Thatcher } \\
\text { Chinese Spring-S-6 I } 5\end{array}$ & $\begin{array}{l}\mathrm{I} \\
\mathrm{I} \\
\mathrm{I} \\
2 \\
\mathrm{I} \\
1 \\
1\end{array}$ & $\begin{array}{l}2 \mathrm{~A}(\mathrm{II})-3 \mathrm{~A} \\
5 \mathrm{~B}-7 \mathrm{~B} \\
3 \mathrm{~B}-3 \mathrm{D} \\
3 \mathrm{~B}-3 \mathrm{D}, 5^{\mathrm{B}-7^{\mathrm{B}}} \\
3 \mathrm{~B}-7 \mathrm{~B} \\
4 \mathrm{~A}-6 \mathrm{~B} \\
2 \mathrm{~B}(\mathrm{XIII})-3 \mathrm{~B}, 4^{\mathrm{A}-6 \mathrm{~B}}\end{array}$ & $\begin{array}{l}\text { Dalal and Sadanaga ( } 1965) \\
\text { Sears (I } 953 \text { ) } \\
\text { Riley (unpublished) } \\
\text { Riley (unpublished) } \\
\text { Sears (r } 953 \text { ) } \\
\text { Sears (I } 953) \\
\text { Larson (1954) }\end{array}$ \\
\hline
\end{tabular}

* Unless otherwise stated the parents belong to T. estivum ssp. vulgare.

of interchange conditions it might be possible to assemble evidence on phylogenetic relationships. The present paper deals with the first exploration of this procedure and demonstrates the existence of hexaploid wheats with the primitive chromosome structure.

\section{MATERIAL}

Meiosis was studied in hybrids among the parental forms listed below.

Triticum astivum L. emend. Thell ssp. vulgare MacKey $(2 n=6 x=42)$ was represented by the varieties:

Chinese Spring A well-established cytogeneticists' "variety", certainly of Chinese origin, and morphologically and physiologically very close to $\mathrm{V}_{12}$ and $\mathrm{V}_{1}$ 3, described below, which were collected from known regions of China.

$\begin{aligned} & \text { Indian } \\ & \text { Holdfast } \\ & \text { Cappelle-Desprez } \\ & \text { Thatcher }\end{aligned}$
$\begin{aligned} & \text { Standard agronomic varieties, the product of hybridisation } \\ & \text { programmes. }\end{aligned}$ April Bearded An old land variety of England.

V 220 From the Pratap Model Farm, Srinagar, Kashmir, in 1930.

V 256 From Pui (Sunjami Tahsil) in the Loralai District of Baluchistan in 1930, where it was known by the local name of "Sur".

V I2 From Tzeliutsing, about roo miles west of Chungking on the Yangtze Kiang in south-western central China, in 1929.

V I3 From T'ungch'uan, about 150 miles north-west of Chungking, China, in 1929.

The four last-mentioned forms were part of a collection originally assembled by Mr A. E. Watkins and maintained at Cambridge ever since. 
T. astivum L. emend. Thell ssp. spelta (L.) Thell was represented by the following varieties or isolates:

Grey Spelt

Schwarzwald

S 157

S I59

S 170

S I 75

$\mathrm{S}_{177}$

A form of European origin maintained at Cambridge for over 40 years.

A form of south-German origin from the collection of Dr S. Wagner of Zurich, named after the place from which it was collected.

One representative of each of the following forms of hexaploid wheat was also employed:

T. astivum L. emend. Thell. ssp. compactum (Host) MacKey n. comb.

T. astivum L. emend. Thell. ssp. spharococcum (Perc.) MacKey n. comb.

T. astivum L. emend. Thell. ssp. macha (Dek. et Men.) MacKey n. comb.

T. astivum L. emend. Thell. ssp. vavilovi (Tam.) Jakub.

Two forms of tetraploid wheat were employed, namely:

T. turgidum L. emend. ssp. dicoccoides Bowden.

T. turgidum L. emend. ssp. carthlicum Bowden ( $=T$. persicum Vav.).

In addition, reference will be made to a hybrid described earlier by two of the present authors (Riley and Chapman, 1960). One of the parents of this hybrid was the diploid species Egilops squarrosa L.

Meiosis was studied in hybrids resulting from 55 distinct crosses between these parental forms.

\section{METHODS}

Anthers were fixed in acetic-alcohol $(1: 3)$ and stained by the Feulgen procedure. Chromosome pairing was usually scored in 65-I oo p.m.c.s, at first metaphase of meiosis, from each hybrid combination. Every cell was scored for the presence or absence of multivalents and where multivalents occurred the number of chromosomes involved and their configuration were recorded. In this way the occurrence and nature of any interchange heterozygosity was established and the relative structures of the parental forms categorised.

\section{THE PRIMITIVE HEXAPLOID STRUCTURE}

Clearly in the initial hexaploid wheat the structure of the chromosomes of the $\mathrm{A}$ and $\mathrm{B}$ genomes must have been identical with that of the chromosomes of the tetraploid form of Triticum from which it was derived. Similarly the structure of the chromosomes of the D genome must have been identical with that of the chromosomes of the parental form of $A$. squarrosa. The determination of the form of $\mathcal{T}$. astivum with the primitive chromosome structure therefore involves the recognition of a form with the same A-B genome structure as a tetraploid Triticum and the same D genome structure as $A$. squarrosa. 
Riley and Chapman (1960) found no multivalents in roo cells of the hybrid $T$. astivum ssp. vulgare Chinese Spring $\times \mathbb{E}$. squarrosa (table 2). In addition to the roo cells scored in detail many more cells were examined, and although the expected seven bivalents were usually formed, a multivalent was never observed (plate $\mathrm{I} a$ ). This demonstrates conclusively that no interchange is present in Chinese Spring that involves a chromosome of the $\mathrm{D}$ genome. The $\mathrm{D}$ genome is thus in its primitive condition.

\section{TABLE 2}

Chromosome pairing at first metaphase of meiosis in the hybrid $\mathrm{T}$. æstivum spp. vulgare Chinese Spring $\times$ Ae. squarrosa

\begin{tabular}{|c|r|r|}
\hline \multicolumn{2}{|c|}{ Pairing } & \multirow{2}{*}{ Cells } \\
\hline Biv. & Univ. & \\
\hline & & \\
\hline 4 & 20 & 1 \\
5 & 18 & 4 \\
6 & 16 & 35 \\
7 & 14 & 60 \\
\hline \multicolumn{2}{|c|}{ Total } & I00 \\
\hline
\end{tabular}

Among the pentaploid hybrids there were no multivalents in those obtained from the cross $T$. astivum ssp. vulgare Chinese Spring $\times T$. turgidum ssp. dicoccoides. The only deviation from the pattern of 14 bivalents and 7 univalents, almost invariably observed in these hybrids, resulted from the failure of pairing giving fewer bivalents and more univalents. Therefore the chromosomes of the A and B genomes of ssp. vulgare Chinese Spring are structurally unchanged relative to those of ssp. dicoccoides. This confirms the work of Dalal and Sadanaga (1965) who found no multivalents in pentaploid hybrids from the cross ssp. vulgare Chinese Spring $\times$ ssp. dicoccum.

On the present evidence it can therefore be concluded that ssp. vulgare Chinese Spring has the primitive chromosome structure of hexaploid wheat. The chromosomes of all other hexaploid wheats can therefore be compared with those of ssp. vulgare Chinese Spring, to determine whether or not deviations from the primitive structure have occurred.

Hybrids from crosses with ssp. vulgare Chinese Spring of only three of the other parental forms examined proved to be structurally homozygous, with no multivalents. The crosses were:

ssp. spelta S I $70 \times$ Chinese Spring (40 cells scored);

ssp. spelta S $175 \times$ Chinese Spring ( 43 cells scored);

ssp. vulgare V $220 \times$ Chinese Spring ( I oo cells scored).

$Q^{2}$ 
No interchanges, therefore, differentiate the four hexaploids Chinese Spring, V 220, S I 70 and S I 75. Therefore the primitive chromosome structure is present in some forms of both ssp. spelta and ssp. vulgare. It will be noted that the ssp. spelta types with the primitive structure originate from Iran, and that the forms of ssp. vulgare come from China and Kashmir.

\section{T. TURGIDUM ssp. CARTHLICUM}

Kihara and his colleagues have, since their synthesis of hexaploid forms from hybrids of the cross ssp. carthlicum $\times \mathbb{E}$. squarrosa, sustained the notion that the tetraploid parent of $T$. astivum might have been ssp. carthlicum (Kihara and Lilienfeld, I949; Kihara, I965).

The present results have a bearing on this theory since one multivalent, indicative of heterozygosity for a single interchange, was found in the hybrids:

ssp. dicoccoides $\times$ ssp. carthlicum ( Ioo cells scored, ro with a multivalent);

ssp. vulgare Chinese Spring $\times$ ssp. carthlicum (62 cells scored, 2 I with a multivalent).

The chromosomes of ssp. carthlicum thus differ from those of the A-B genomes of the primitive hexaploid by a single interchange. This indicates that a form of ssp. carthlicum with the same chromosome structure as that used in the present work could not have been the tetraploid parent of hexaploid wheat. This interpretation is supported by the equivalent results with hybrids from the same cross studied by Dalal and Sadanaga (1965) (table I).

It could of course be argued that ssp. carthlicum might have acquired the interchange by which it is differentiated from the primitive hexaploid subsequent to its participation in the parentage. However, the presence of this interchange must place considerable doubt in the significance of ssp. carthlicum in the evolution of $T$. astivum. The removal of this doubt requires the recognition of forms of ssp. carthlicum and of T. estivum with corresponding chromosome struciures in the $\mathrm{A}$ and $\mathrm{B}$ genomes.

\section{DEVIANTS FROM THE PRIMITIVE HEXAPLOID STRUCTURE}

Having established the primitive chromosome structure of ssp. vulgare Chinese Spring, the structures of all the other hexaploids can be related to that of Chinese Spring. This was accomplished by the study of meiosis in hybrids between Chinese Spring and all the other hexaploids involved in the investigation. The results with these hybrids can be divided according to the number of interchanges for which the hybrids were heterozygous. 


\section{(i) Single interchange heterozygotes}

The behaviours of the hybrids, involving Chinese Spring, heterozygous for a single interchange are recorded in table 3 . The frequency with which interchange heterozygosity was expressed by the formation of a multivalent differed widely between hybrids. Despite the infrequency of multivalents in the hybrids involving ssp. vulgare April Bearded and ssp. vavilovi, the differentiation of these parents from the primitive structure by a single interchange was confirmed from peripheral crosses described later.

\section{TABLE 3}

Frequencies of multivalents in hybrids involving Chinese Spring, showing heterozygosity for one interchange relative to the primitive hexaploid chromosome structure

\begin{tabular}{|c|c|c|}
\hline $\begin{array}{c}\text { ssp. vulgare } \\
\text { Chinese Spring } \times\end{array}$ & $\begin{array}{l}\text { Cells } \\
\text { scored }\end{array}$ & $\begin{array}{l}\text { Per cent. cells with } \\
\text { one triv. or quad. }\end{array}$ \\
\hline $\begin{array}{l}\text { ssp. vulgare Indian } \\
\text { ssp. vulgare Holdfast } \\
\text { ssp. vulgare Thatcher } \\
\text { ssp. vulgare April Bearded } \\
\text { ssp. vulgare V } 256 \\
\text { ssp. vulgare V I } 2 \\
\text { ssp. vulgare V I } 3 \\
\text { ssp. spelta Grey Spelt } \\
\text { ssp. spelta Schwarzwald } \\
\text { ssp. spelta S I } 57 \\
\text { ssp. spelta S I } 59 \\
\text { ssp. spelta S I } 77 \\
\text { ssp. compactum } \\
\text { ssp. vavilovi }\end{array}$ & $\begin{array}{r}100 \\
100 \\
70 \\
100 \\
72 \\
100 \\
100 \\
100 \\
100 \\
24 \\
20 \\
20 \\
100 \\
100\end{array}$ & $\begin{array}{r}82 \\
16 \\
31 \\
2 \\
8 \\
51 \\
65 \\
20 \\
68 \\
12 \\
15 \\
15 \\
13 \\
2\end{array}$ \\
\hline
\end{tabular}

Five forms of ssp. spelta deviated from the primitive chromosomal structure by a single interchange (table 3 ). Two of these were European and three Iranian forms. As has already been pointed out two forms of ssp. spelta examined had the primitive structure. Consequently, as with ssp. vulgare, there is intra-subspecific differentiation for interchange conditions in ssp. spelta.

\section{(ii) Double interchange heterozygotes}

Three hexaploid forms, ssp. vulgare Cappelle-Desprez, ssp. spherococcum and ssp. macha, were shown to possess chromosome structures differentiated from the primitive structure by two interchanges (table 4). In the case of ssp. vulgare Cappelle-Desprez and ssp. macha evidence of this was obtained directly since their hybrids with Chinese Spring had some meiotic cells with two multivalents. The situation was not so simple with ssp. spharococcum, however, since no cells in its hybrids with Chinese Spring contained two multivalents. Nevertheless, very convincing evidence of the presence of two interchanges was 
obtained from peripheral hybrids between ssp. spherococcum and other hexaploids with non-primitive structures (see below).

TABLE 4

Frequencies of multivalents in hybrids, involving Chinese Spring, heterozygous for two translocations relative to the primitive hexaploid chromosome structure

\begin{tabular}{|l|c|c|c|}
\hline & \multirow{2}{*}{ ssp. vulgare Chinese Spring $\times$} & $\begin{array}{c}\text { Cells } \\
\text { scored }\end{array}$ & \multicolumn{2}{|c|}{ Per cent. cells with: } \\
\cline { 3 - 4 } & & One triv. or quad. & Two trivs. or quads. \\
\hline ssp. vulgare Cappelle-Desprez & 100 & 64 & 3 \\
ssp. spharococcum & & & $\ldots$ \\
ssp. macha & 100 & 56 & 7 \\
\hline
\end{tabular}

* Evidence of two interchanges in ssp. spharococcum was derived from peripheral crosses table 6).

\section{INTERCHANGE RELATIONSHIPS BETWEEN FORMS WITH NON-PRIMITIVE CHROMOSOME STRUCTURES}

The relationships of the forms tested against ssp. vulgare Chinese Spring, and found to have chromosome complements that deviate from the primitive structure by the presence of one or two interchanges, are depicted in fig. I. The forms with the primitive structure, including ssp. vulgare Chinese Spring, must obviously be placed in a central position relative to which those with non-primitive structures occupy radial situations. Clearly the structures of the non-primitive forms can be compared, in appropriate hybrids, to ascertain whether corresponding interchanges are present. This procedure was carried out for a number of comparisons which are most readily described first in terms of the relative structure of the non-primitive hexaploids and secondly in terms of the structures of ssp. carthlicum relative to that of a range of hexaploids.

\section{(i) Non-primitive hexaploids}

Four forms of ssp. vulgare, with differences from the primitive structure of ssp. vulgare Chinese Spring due to identified interchanges (table I), were used as testers against which were compared the structures of forms differing from the primitive structure by unidentified interchanges. The tester forms were the varieties Indian with a ${ }_{3} \mathrm{~B}-7 \mathrm{~B}$ interchange, Holdfast with a ${ }_{3} \mathrm{~B}-3 \mathrm{D}$ interchange, CappelleDesprez with ${ }_{3} \mathrm{~B}-3 \mathrm{D}$ and ${ }_{5} \mathrm{~B}-7 \mathrm{~B}$ interchanges and Thatcher with a $4 \mathrm{~A}-6 \mathrm{~B}$ interchange. These were crossed with a range of hexaploids with non-primitive structures and meiosis was examined in the hybrids. The numbers of interchanges heterozygous in the hybrids, and by which the parents were differentiated, were determined from the cells with the maximum number of multivalents (table 5) (plate $\mathrm{I} b$ and $c$ ). The relationships determined in this way are depicted in fig. $\mathrm{I}$. 
TABLE 5

Numbers of interchanges in hybrids between hexaploid forms with non-primitive chromosome structures

\begin{tabular}{|c|c|c|c|c|}
\hline \multirow{2}{*}{ Parents } & \multicolumn{4}{|c|}{ ssp. vulgare tester forms } \\
\hline & Indian & Holdfast & Cappelle-Desprez & Thatcher \\
\hline $\begin{array}{l}\text { ssp. vulgare April Bearded } \\
\text { ssp. vulgare V } 256, V_{1} 2 \text {, and V I } 3 \\
\text { ssp. spelta Grey Spelt } \\
\text { ssp. compactum } \\
\text { ssp. spharococcum } \\
\text { ssp. macha } \\
\text { ssp. vavilovi }\end{array}$ & $\begin{array}{l}2 \\
2 \\
2 \\
2 \\
3^{*} \\
3^{*} \\
2\end{array}$ & $\begin{array}{c}\ldots \\
\cdots \\
2 \\
\cdots \\
3 * \\
\cdots \\
\cdots\end{array}$ & $\begin{array}{c}\cdots \\
\text { I } \\
\cdots \\
3^{*} \\
\cdots \\
\cdots \\
\text { I }\end{array}$ & $\begin{array}{c}\cdots \\
2 \\
2 \\
2 \\
1 \\
3^{*} \\
\cdots\end{array}$ \\
\hline
\end{tabular}

* These hybrids had a pentavalent or a hexavalent indicating that two of the heterozygous interchanges involved only three pairs of chromosomes.

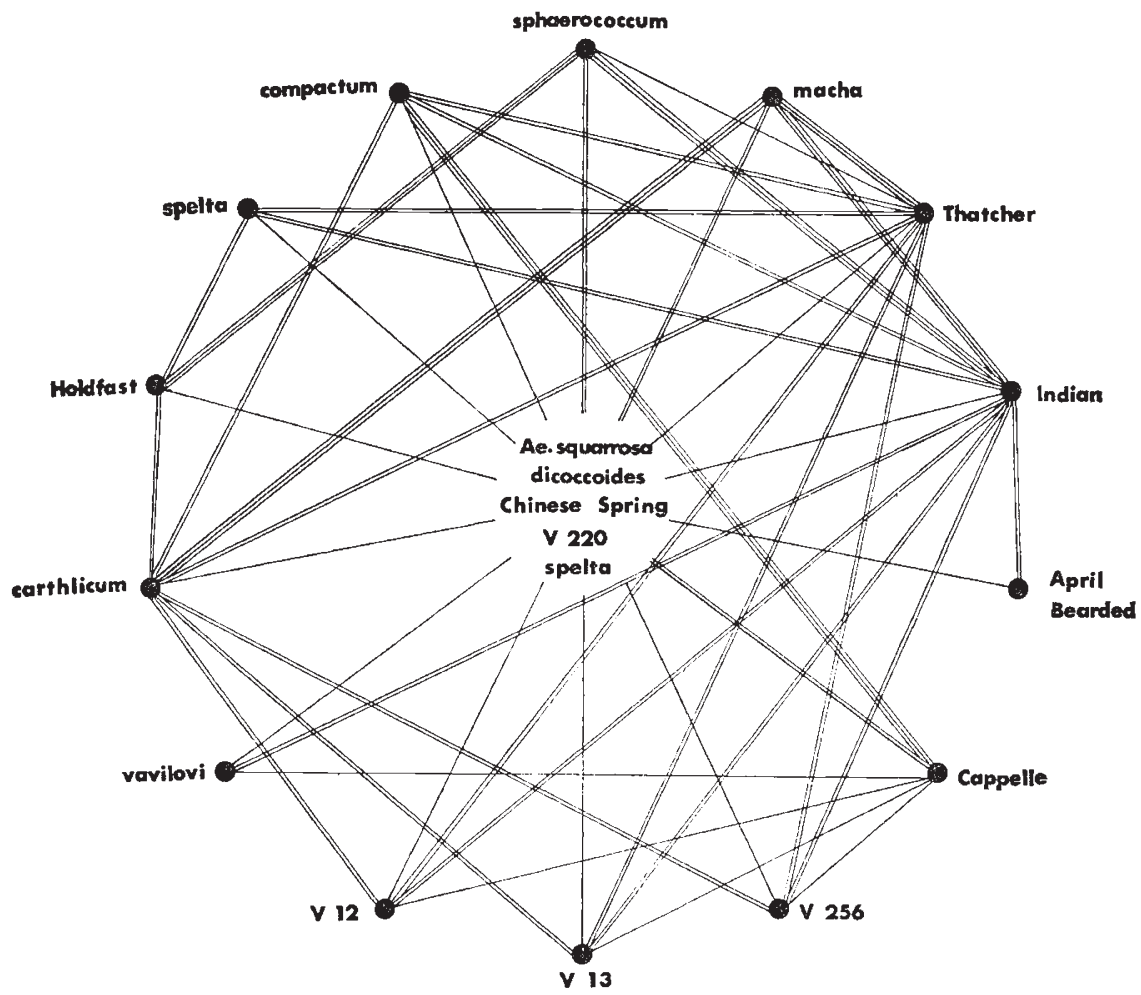

FIG. I.-A diagram showing the numbers of interchanges by which the forms of Triticum studied are differentiated. Forms placed together have no interchange difference, those connected by one, two or three lines differ by one, two or three interchanges respectively. Dicoccoides and carthlicum are subspecies of T. turgidum. Spelta, compactum, spharococcum, macha and vavilovi are subspecies of $T$. astivum. T. cestivum ssp. vulgare is represented by the varieties Chinese Spring, Indian, Holdfast, Cappelle (=Cappelle-Desprez), Thatcher, April Bearded, $\mathrm{V}_{220}, \mathrm{~V}$ 256, $\mathrm{V}_{\mathrm{I}} 2, \mathrm{~V} \mathrm{I}_{3}$. 
The relationships recognised were all internally consistent. For example ssp. vulgare Indian and April Bearded, both of which differed from the primitive Chinese Spring structure by one interchange, differed from each other by two interchanges. In a similar way ssp. vulgare Thatcher and ssp. macha, which differed from the primitive Chinese Spring structure by one and two interchanges respectively, differed from each other by three interchanges. Comparable and consistent triangles of relationships occurred throughout all the tests made on these hybrids (fig. I).

In only one set of comparisons was there evidence leading to the partial identification of an interchange in forms with an unknown structural distinction from the primitive hexaploid complement. This arose from the behaviour of crosses of ssp. vulgare Cappelle-Dexprez with ssp. vavilovi and with the ssp. vulgare varieties $\mathrm{V} 256, \mathrm{~V} \mathrm{I}_{2}$ and $\mathrm{V} \mathrm{I}_{3}$. All four of these alternative parents differed from ssp. vulgare CappelleDesprez by one interchange and from ssp. vulgare Chinese Spring by one interchange, while Chinese Spring and Cappelle-Desprez differed by the ${ }_{3} \mathrm{~B}-3 \mathrm{D}$ and the ${ }_{5} \mathrm{~B}-7 \mathrm{~B}$ interchanges. Therefore the four alternative non-primitive parents must have differed from Cappelle-Desprez by either the ${ }_{3} \mathrm{~B}-3 \mathrm{D}$ or the ${ }_{5} \mathrm{~B}-7 \mathrm{~B}$ interchange and from Chinese Spring by the interchange not involved in the Cappelle-Desprez difference. The likelihood is that all four have the same structure-differing from the primitive structure by the same interchange. If this were the ${ }_{3} \mathrm{~B}-3 \mathrm{D}$ interchange these forms would correspond with ssp. vulgare Holdfast. However, it is more likely that the interchange concerned is that between chromosomes $5^{\mathrm{B}}$ and ${ }_{7} \mathrm{~B}$. In either case the situation can be clarified from the study of hybrids between the four critical forms and between these forms and ssp. vulgare Holdfast. If the condition is as appears the more likely, namely that these forms carry the ${ }_{5} \mathrm{~B}-7 \mathrm{~B}$ interchange, then it may be inferred that ssp. vulgare CappelleDesprez, and the French varieties from which it was derived, include in their parentage European forms like ssp. vulgare Holdfast and Asiatic forms like ssp. vulgare $\mathrm{V} 256$ or ssp. vavilovi.

There was a fairly complex pattern of interchange relationships between the Triticum forms employed in this work (fig. I). A minimum of seven distinct interchange conditions must be postulated to account for the differences involved. Interchanges have thus occurred fairly commonly in the evolutionary diversification of $T$. astivum.

\section{(ii) Ssp. carthlicum}

Meiosis was studied in pentaploid hybrids from crosses between a range of forms of the hexaploid $T$. astivum, all with non-primitive chromosome structures, and the tetraploid T. turgidum ssp. carthlicum. Ssp. carthlicum has already been shown to have a chromosome complement which differs from that of ssp. dicoccoides, and from the structure of the primitive $\mathrm{AB}$ genomes of the hexaploid, by a single interchange. 
There was apparently heterozygosity for either two or three interchanges in hybrids from all seven crosses (table 5). While the presence of heterozygosity for two interchanges was usually indicated by the occurrence in some cells of two multivalents, the observations were not always so straightforward. For example, in the crosses involving ssp. vulgare Holdfast and ssp. vulgare $\mathrm{V} 25^{6}$, no cell was found with two multivalents. However, while some cells had one quadrivalent, I2

TABLE 6

Frequencies of multivalents and interchanges heterozygous in hybrids between ssp. carthlicum and hexaploid wheats with non-primitive chromosome structures

\begin{tabular}{|c|c|c|c|c|c|}
\hline \multirow{2}{*}{ ssp. carthlicum $\times$} & \multirow{2}{*}{$\begin{array}{l}\text { Cells } \\
\text { scored }\end{array}$} & \multicolumn{3}{|c|}{ Per cent. cells with: } & \multirow{2}{*}{$\begin{array}{l}\text { Interchanges } \\
\text { heterozygous }\end{array}$} \\
\hline & & $\begin{array}{l}\text { One triv. } \\
\text { or quad. }\end{array}$ & $\begin{array}{l}\text { Two trivs. } \\
\text { or quads. }\end{array}$ & $\begin{array}{c}\text { One penta. } \\
\text { or hexa. }\end{array}$ & \\
\hline ssp. vulgare Holdfast* & $2 \mathrm{I}$ & I 9 & $\cdots$ & $\cdots$ & 2 \\
\hline ssp. aulgare Thatcher & 65 & $4 I$ & 3 & $\cdots$ & 2 \\
\hline ssp. vulgare $\mathrm{V} 256^{*}$ & 62 & 25 & ... & $\cdots$ & 2 \\
\hline ssp. vulgare V 12 & 63 & 42 & 2 & $\cdots$ & 2 \\
\hline ssp. vulgare $V$ I 3 & 62 & 42 & 3 & $\cdots$ & 2 \\
\hline ssp. compactum & 64 & $4^{8}$ & $\cdots$ & 6 & 2 \\
\hline ssp. macha $\dagger$ & 70 & 47 & 9 & $\cdots$ & 3 \\
\hline
\end{tabular}

* Evidence of heterozygosity for two interchanges provided by the occurrence in some cells of ${ }_{12}{ }^{I I}{ }_{1}$ IV ${ }_{7}$ (implying an $A B$ interchange) and in others of ${ }_{1}{ }^{\text {II }}{ }_{\text {I }}^{\text {III }} 6^{\mathrm{I}}$ (implying an $\mathrm{AB}-\mathrm{D}$ interchange).

$\dagger$ Evidence of heterozygosity for three interchanges was provided by the occurrence of some cells with I II III $_{\text {IV }} 6^{1}$ (implying one $\mathrm{AB}$ and one $\mathrm{AB}$ with $\mathrm{D}$ interchange) and others with ${ }_{12}{ }^{\mathrm{II}}{ }_{2}{ }^{\mathrm{III}} 5^{1}$ (implying two $\mathrm{AB}$ with $\mathrm{D}$ interchanges).

bivalents and seven univalents, indicating interchange heterozygosity within the $\mathrm{AB}$ genomes, others had one trivalent, I 3 bivalents and six univalents, indicating heterozygosity for an interchange between an A or B and a D genome chromosome.

Similarly in the cross with ssp. macha, some cells had patterns of pairing revealing heterozygosity for one interchange between chromosomes of the $\mathrm{A}$ or $\mathrm{B}$ and the $\mathrm{D}$ genomes and one within the $\mathrm{AB}$ genomes. Other cells, however, revealed heterozygosity for two interchanges between $\mathrm{A}$ or $\mathrm{B}$ and $\mathrm{D}$ genome chromosomes. These hybrids were therefore apparently heterozygous for three interchanges, one within the $\mathrm{AB}$ genomes and two between $\mathrm{A}$ or $\mathrm{B}$ and $\mathrm{D}$ genome chromosomes.

The results from a number of the hybrids, involving ssp. carthlicum as one of the parents, were inconsistent with each other when considered in relation to all the other evidence of interchanges. The inconsistency, which cannot be explained on the evidence currently available, concerned the genomic distributions of the chromosomes involved in the interchanges by which the parents apparently differed. Meiosis in hybrids from the crosses ssp. dicoccoides $\times$ ssp. carthlicum, ssp. vulgare Thatcher $\times$ ssp. carthlicum and ssp. vulgare Holdfast $\times$ ssp. carthlicum, 
indicated that the interchange, by which the complement of ssp. carthlicum differs from the primitive chromosome structure of the hexaploids, involves chromosomes of the $\mathrm{AB}$ genomes. By contrast the meiotic behaviour of hybrids from the crosses ssp. vulgare V $220 \times \mathrm{ssp}$. carthlicum, ssp. macha $\times$ ssp. carthlicum and ssp. compactum $\times$ ssp. carthlicum, could only be interpreted as meaning that the critical interchange, by which the structures of ssp. carthlicum and the primitive hexaploids are differentiated, is between chromosomes of the A or B genome and of the $\mathrm{D}$ genome. If the latter were true it would mean that the ssp. carthlicum parent had the primitive $\mathrm{AB}$ genome structure and that the structure of ssp. vulgare $\mathrm{V} 220$ was not that of the primitive hexaploid. This is incompatible with much other evidence so that no generally acceptable interpretation of the interchange relationships of ssp. carthlicum is possible.

One possibility, that is worth detailed study, is that the genetic control of meiotic pairing specificity exercised by chromosome $5^{\mathrm{B}}$ (Riley and Law, I965), is disturbed in pentaploid hybrids involving ssp. carthlicum. If this were so the multivalents observed in these hybrids would not always indicate interchange heterozygosity. Dalal and Sadanaga (1965) encountered difficulties, similar to those met in the present analysis, in their attempts to identify the chromosomes involved in the interchange that is heterozygous in hybrids from the cross ssp. vulgare Chinese Spring $\times$ ssp. carthlicum. They also suggested that a disturbance of the genetic control of the specificity of meiotic pairing might be responsible.

\section{DISCUSSION}

The present work constitutes a first attempt to describe phylogenetic relationships in Triticum in terms of the chromosomal interchanges that have occurred fairly commonly in the evolution of the genus. The persistence of the derived interchange conditions allows something of the pattern of evolution to be discerned from the relative structural arrangements of various forms. However, before attempting a general interpretation of the results, one qualification concerning their general validity is necessary. This arises from the need to recognise that only one form each of a number of the subspecies of $T$. astivum was employed. The structures of the forms of ssp. compactum, spharococcum, macha and vavilovi, used in the present studies, may or may not be typical of the entire range of their respective subspecies. The possibility cannot be ignored that these subspecies, like ssp. vulgare and spelta, may contain forms with different interchange conditions. This is not very likely in ssp. spharococcum, macha and vavilovi, which are relatively circumscribed, but is more likely in compactum which is a larger subspecies.

With this qualification in mind, the overall implications of the presently available knowledge of the distributions of interchanges can be considered. Perhaps the most significant outcome has been the observation that the primitive hexaploid structure, with the $\mathrm{A}$ and $\mathrm{B}$ 
genomes unchanged from a tetraploid condition and the D genome unchanged from the $E$. squarrosa condition, was found only in ssp. vulgare and ssp. spelta. On the simplest interpretation this means that none of the other subspecies of $\mathcal{T}$. estivum could have been the archetype of hexaploid wheat. Those favouring some subspecies other than vulgare or spelta as the primitive hexaploid must provide evidence of the existence of a form with the primitive structure of, for example, ssp. vulgare Chinese Spring. Alternatively they must make the assumption that the primitive structure of the archetype now persists only in its derivatives in ssp. vulgare and spelta. This latter proposal seems unlikely and is $a b$ initio incapable of proof so that a clear necessity for the demonstration of structural identity with ssp. vulgare Chinese Spring is essential before any hexaploid can be thought of as primitive.

The evidence at present available allows the acceptance of only ssp. vulgare or ssp. spelta as the first hexaploid. Ssp. vulgare differs from ssp. spelta primarily in having the dominant allele $Q$ rather than the recessive $q$ at the locus which determines important attributes of spike morphology (Sears, 1956). The $q$ allele, when homozygous, causes the spike to be non-square-headed and brittle, and the grain to be closely invested by the chaff. By contrast the $Q$ allele leads to the formation of a square-headed spike with a tough rachis and to the occurrence of free-threshing grains. Clearly mutation could have taken place in either direction in the derivation of one of these forms from the other so that it is of some interest to consider whether any guidance is given by the distribution of interchange conditions.

The only forms of ssp. spelta with the primitive structure were some of those collected in the Baktrian area of Iran by Kuckuck (r959). Other forms of ssp. spelta, also originating from the same area, differed from the primitive structure by a single interchange, as did the European forms examined. Some estimate of the antiquity of ssp. spelta will be gained by the determination of whether or not the same interchange is present in both the Iranian and European forms. If these very disjunct forms possess the same chromosome structures, the interchange, by which they are differentiated from the primitive structure, is very ancient. Indeed the interchange must presumably have been present in the populations of ssp. spelta that were widespread in Europe and the Near East when the whole of this area was controlled by the Roman Empire. The conclusion would then be inevitable that the forms of ssp. spelta, now found in widely separated localities, did not originate independently from ssp. vulgare, but that they represent relics of an originally continuous pattern of distribution. This could support the notion that ssp. spelta was the primitive hexaploid.

Only two forms of ssp. vulgare, with the primitive chromosome structure, were included among those studied. These were the varieties Chinese Spring and V 220 both of which originate from the more easterly range of the distribution of the subspecies. Although $\mathrm{V}_{220}$ was collected in Kashmir it may well have been ultimately derived 
from further east. It is of some interest that other primitive features, such as ready crossability with rye, are also retained primarily by eastern forms of ssp. vulgare. Since the hexaploid wheat cannot have originated in China, because this area is outside the natural range of tetraploid wheat and E. squarrosa, it must be ccncluded that those forms, introduced into China along the "Silk Road" probably in the first millennium B.c. (Kihara and Lilienfeld, ı949; Yü, I96I), were preserved from the pressures that led to evolutionary changes in the forms remaining closer to the centre of origin.

The evidence of chromosome structure is quite compatible with the notion that ssp. vulgare was the initial hexaploid from which all the other hexaploid subspecies were derived. A study of the geographical distribution of the primitive chromosome structure in ssp. vulgare would probably assist in assessing its primitiveness. All that can be said at present, is that there is a strong possibility that ssp. vulgare is primitive and that interpretation of the biological evidence accords with the archæological findings which show the presence of free-threshing hexaploids wheats at the earliest levels before the appearance of ssp. spelta (Helbaek, I964).

\section{SUMMARY}

I. Study of hybrids among a range of tetraploid and hexaploid forms of Triticum has shown that evolutionary relationships can be determined by the relative chromosome structures of the parents concerned. Many parents were differentiated by chromosomal interchanges.

2. Two forms of $\mathcal{T}$. estivum, ssp. vulgare and of ssp. spelta, have the primitive hexaploid chromosome structure. They had no interchanges in the $\mathrm{A}$ and $\mathrm{B}$ genomes relative to the tetraploid T. turgidum ssp. dicoccoides or in the $\mathrm{D}$ genome relative to the diploid $\not$ E. squarrosa.

3. All the other hexaploids, including other forms of ssp. vulgare and spelta, as well as one representative each of ssp. compactum, spharococcum, macha and vavilovi, differed from the primitive structure by one or two interchanges.

4. On the present evidence the first hexaploid wheat must have been either ssp. vulgare or ssp. spelta.

\section{REFERENCES}

AAronsonn, A. I9ro. Agricultural and botanical explorations in Palestine. U.S.A. Dept. Agr., Bureau of Pl. Ind. Bull., 180 .

DALAL, K. C., AND SADANAGA, K. I965. Identification of the chromosomes involved in translocation in $F_{1}$ hybrid of two species of tetraploid wheat. Can. F. Genet. Cytol., 7, 88-95.

Helbaek, H. 1964. Archeological evidence for genetic changes in wheat and barley. Pl. Introd. Rev., Canberra, 2, 10-16.

kIHARA, H. I965. The origin of wheat in the light of comparative genetics. Fap. 7 . Genet., 40, 45-54.

kihara, H., AND lilienfeld, F. 1949. A new synthesized 6x-wheat. Proc. VIII Int. Congr. Genet., 307-319. 


\section{Plate I}

First metaphase of meiosis in Triticum $\times$ Agilops or Triticum $\times$ Triticum hybrids. (a) $T$. estivum ssp. vulgare Chinese Spring $\times \mathscr{E}$. squarrosa with seven bivalents and 14 univalents. There is no interchange difference between these parents: (b) $T$. astivum ssp. vulgare Indian $\times T$. astivum ssp. vulgare $V_{12}$ with 17 bivalents and two quadrivalents. The parents differ by two interchanges: (c) T. estivum ssp. spherococcum $\times T$. astivum ssp. vulgare Indian with 18 bivalents and one hexavalent. The parents differ by three interchanges two of which involve only three pairs of chromosomes. 


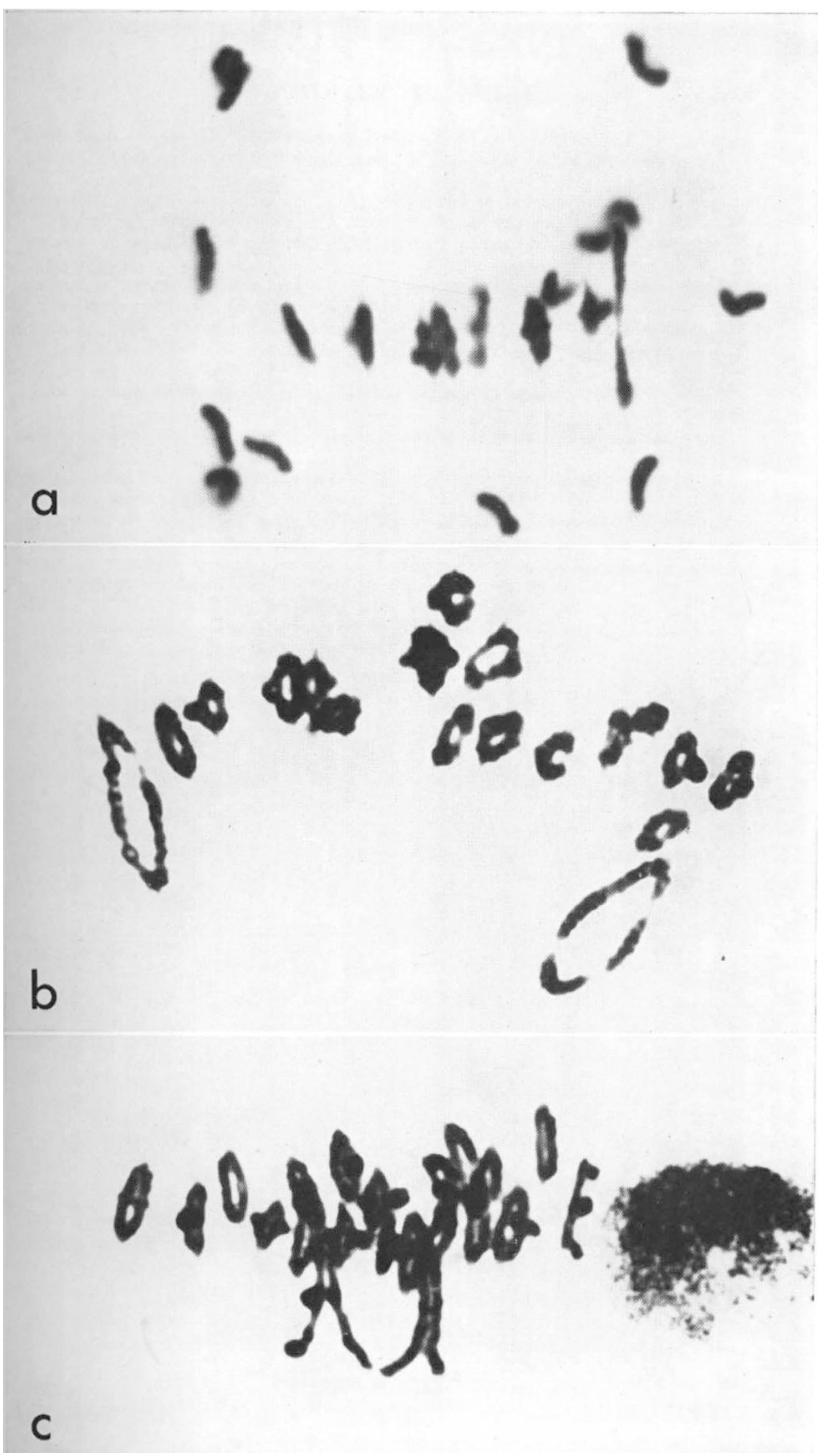


KUGKUCK, H. I959. On the findings of Triticum spelta $\mathrm{L}$. in Iran and on the arising of Triticum astivum-types through crossing of different spelta-types. Wheat Inf. Serv., 9-IO, I-2.

MGFADDEN, E. S., AND SEARS, E. R. I946. The origin of Triticum spelta and its freethreshing hexaploid relatives. F. Hered., 37, 8 I-89, го7-г 6 .

MAGKeY, J. I954a. The taxonomy of hexaploid wheat. Svensk. bot. Tidskv., $4^{8}$, 579-590.

MAGKEY, J. $1965 b$. Neutron and X-ray experiments in wheat and a revision of the speltoid problem. Hereditas, $40,65-180$.

RILEY, R. 1965. Cytogenetics and the evolution of wheat. In Essays on Crop Plant Evolution. Ed. J. B. Hutchinson. Cambridge University Press, Cambridge, pp. I03-II8.

RILEY, R., AND CHAPMAN, v. Ig6o. The D genome of hexaploid wheat. Wheat Inf. Serv., $I I$, I 8.

RILey, R., AND LAW, G. N. 1965. Genetic variation in chromosome pairing. Adv. Genet., 13, 57-107.

schiemann, e. I93I. Pfahlbauweizen. Historisches und phylogenetisches. Z.f. Pflanzenzuchtg., $17,36-54$.

schiemann, E. I95I. New results on the history of cultivated cereals. Heredity, 5, 305-320.

SEARs, E. R. I956. Weizen (Triticum L.) I. The systematics, cytology and genetics of wheat. Sonderdruck aus. Handbuch der Pflanzenzüchtung, 2, I64-187.

yü, C-J. I96I. The Rivet wheat in north western China: A comment on Dr Hosono's hypothesis on the route of introduction of wheat into China. Wheat Inf. Serv., I2, 4-5. 